\title{
Student or Teacher: The Tensions Faced by a Spanish Language Student Teacher
}

\author{
Gloria Vélez-Rendón \\ Assistant professor of Spanish and Foreign Language Education \\ Purdue University Calumet Hammond, IN 46323 \\ velezre@calumet.purdue.edu
}

\begin{abstract}
The contradictory realities of student teaching viewed through the student teachers' eyes have been the focus of attention of some recent publications (Britzman, 1991; Knowles \& Cole, 1994; Carel, S.; Stuckey, A.; Spalding, A.; Parish, D.; Vidaurri, L; Dahlstrom, K.; \& Rand, Ch., 1996; Weber \& Mitchell, 1996). Student teachers are "marginally situated in two worlds" they are to educate others while being educated themselves (Britzman, 1991, p. 13). Playing the two roles simultaneously is highly difficult. The contradictions, dilemmas, and tensions inherent in such endeavor make the world of the student teacher increasingly problematic. This is further complicated by the power relationships that often permeate the student teacher cooperating teacher relationship.
\end{abstract}

This paper describes salient aspects of the student teaching journey of Sue, a white twenty-two year old student teacher of Spanish. It uncovers the tensions and dilemmas experienced by the participant in her quest for professional identity. Data collection sources for this study included (a) two open-ended interviews, each lasting approximately forty-five minutes; (b) one school-day lons observation; and (c) a copy of the communication journal between the participant and her cooperating teacher.

The data revealed that soon upon entering the student teaching field 
experience, Sue found herself torn by the ambiguous role in which student teachers are positioned: she was neither a full-fledsed teacher nor a student. In trying to negotiate a teaching role for herself, Sue was pulled in different directions. She soon became aware of the powerful position of the cooperating teacher and of her vulnerability within the mentoring relationship. The main tension was manifested in Sue's strugsle to develop her own teaching persona on the one hand, and the pressure to conform to her cooperating teachers' expectations on the other hand. The implications of the study are discussed.

\section{RESUMEN}

En este artículo se examina la experiencia de Sue, una mujer blanca, de 22 años, durante su práctica docente en el área de español como lengua extranjera. Se deja al descubierto las tensiones y dilemas que la participante vivió en su búsqueda por una identidad profesional. Los métodos de recolección de datos para este estudio incluyeron (a) dos entrevistas, cada una de aproximadamente 45 minutos; (b) una observación de un día escolar; y (c) una copia del diario de comunicación entre la participante y la profesora cooperadora. El análisis de datos reveló que tan pronto como empezó la práctica docente, la participante se vio en la ambizua posición en que los practicantes s encuentran: no era una educadora con todas las de la ley pero tampoco una estudiante. En su intento por negociar una identidad de educadora, Sue se vio jalonada en diferentes direcciones. La participante pronto adquirió conciencia del poder que ostentaba la profesora cooperadora y de su vulnerable posición en esta relación. La lucha de la participante por mantener su propia identidad, por una parte, y llenar las expectativas de la profesora cooperadora, por otra parte, se constituyeron en la principal fuente de tensión. Al final del artículo se discuten las implicaciones de esta investigación.

\section{INTRODUCTION AND REVIEW OF THE LITERATURE}

The contradictory realities of student teaching viewed through the student teachers' eyes have been the focus of attention of some recent publications (Britzman, 1991; Knowles \& Cole, 1994; Weber \& Mitchell, 1996). For Britzman (1991, p. 13) student teachers are "marginally situated in two worlds." They are expected to educate others while being educated themselves. Playing the two roles simultaneously is highly difficult. The contradictions, dilemmas, and tensions inherit in such endevour make the world of the student teacher "persistently problematic" (Britzman, 1991, p. xiii). Weber \& Mitchell (1996) 
view student teaching as a subculture in which its members struggle to develop professional identity as they seek membership in the more overarching and prestigious culture of teaching. After analyzing the contents of open-ended interviews and narrative accounts of 30 foreign student teachers, the researchers identified four thematic patterns that accounted for the contradictions and tensions present in the socialization process of these student teachers. The four patterns included: (1)Seeing oneself as an outsider; (2) Adapting to the cultural expectations of the wider culture of teaching;(3) Asserting one's own professional identity; and (4) Confronting reality and coping with disappointment. For Weber and Mitchell (1996), student teacher's ability to make a smooth transition from their subculture into the wider culture of teaching depends on several variables. One important factor is the match of student teachers' beliefs, background, and teaching style with those of their teacher educators and cooperating teachers. For instance, student teachers' perspectives on issues such as error correction, teaching approaches, and grammatical drills, play an important role on whether they are able to fit in the wider culture of foreign language teaches.

In Voices from the Trenches, another study focusing on preservice language teachers' emerging identity, the duality of the student teacher role is viewed through the eyes of a teacher educator and her students ( Carel,S.; Stuckey, A.; Spalding, A.; Parish, D.; Vidaurri, L; Dahlstrom, K.; E Rand, Ch., 1996). In her narrative, the teacher educator pondered about the problematic duality of the nature of student teaching. She viewed student teachers continuously moving from one role to the other, wearing their students' hats one moment and their teacher's hats the next, depending on the situation. In their search for identity, student teachers mirrored their cooperating teachers and adopted their traits. It was only towards the end of the term that their individualized characteristics and style started to emerge. Through the voices of the student teachers, we learn that student teaching is a time often plagued by anxieties, concerns, tensions and numerous contradictions.

The literature reviewed shed some light into the issues involved in students teachers' socialization and identity formation. However, research dealing with this topic is still scarce. Inquiry focusing exclusively in pre-service foreign language teacher socialization will enable us to gain insights into what it means to learn to teach a foreign language, how pre-service teachers gain access to the wider culture of teaching and how this process of acculturation impacts 
student teachers' emerging perceptions of themselves as foreign language teachers. Studies of this nature are relevant for language teacher education programs in general, including the ones in the Colombian context, because they illuminate some of the issues involved in learning to teach and provide an instance against which the realities faced by student teachers in Colombia during their student teaching, can be compared.

Following is the final report of a research project ${ }^{1}$ that seeks to contribute to our nascent understanding of this topic. The research report is based on a case study that describes the student teaching experience of Sue. The purpose of the case study was to examine how the participant lived her transition from student to teacher and what meanings she attached to this experience.

\section{METHODOLOGY}

A qualitative study using the lenses of phenomenology was considered appropriate to capture the lived experiences of the participant as she initiated her journey towards becoming a foreign language teacher. Phenomenology is concerned with experiences as they appear in consciousness. The phenomenological-oriented research focuses on the experiences as lived by the participants and on the meanings they attach to them. The underlying assumption is that reality is what participants perceive it to be (Kvale,1996). Thus, the purpose and challenge of a phenomenological-oriented study is to render an account of how a person experiences his/her own world from his/her point of view (Moustakas, 1994).

\section{PARTICIPANT AND SITE}

The participant of this study was Sue, a white 22-year, old female student teacher of Spanish. The study was conducted at Central High School where Sue was placed to complete her student teaching assignment during the spring semester of 1998. Mrs. Sarah Smith was Sue's cooperating teacher. Mrs. Smith was also Anglo and had been a Spanish language teacher at Central for 7 years. Both Sue and Mrs. Smith were nonnative speakers of Spanish. All proper names

1 This is an institutional research project. 
used in this case study are fictitious to protect the participant's identity.

\section{DATA COLLECTION AND ANALYSIS}

Data collection procedure comprised (a) two open-ended interviews with Sue, each lasting approximately forty-five minutes, (b) one school-day long observation and (c) a copy of the communication journal between the participants and her cooperating teacher.

Data analysis consisted of scrutinizing the data thoroughly and carefully to search for salient patterns following the procedures outlined by Strauss $\mathcal{E}$ Corbin (1990).Substantial evidence was found that revealed the problematic nature of student teaching in this specific case in order to organize the data and report the findings, I developed a case study to preserve the integrity of the participant's experience and construct a narrative that would bring it alive (Yon, 1984). Data clips taken from the interview transcripts and from the communication journal are used increasingly to provide evidence and reveal the participant's perspective. Following are the findings weaved in a narrative of Sue's journey to become a Spanish language teacher.

\section{FINDINGS: SUE'S STORY}

Except for the time when Sue was two and wanted to be a plumber, she always knew that she wanted to be a teacher. Born to parents who were teachers themselves, this friendly, confident, and enthusiastic, twenty-two-year-old student teacher was "already naturally teaching" her peers at a very young age. In second grade, she started thinking about how she could teach others. When she went to college, it was just a matter of deciding what she would teach. Sue vacillated between speech communication, theater, elementary school, and Spanish. Key in her decision to pursue a Spanish degree was the influence of two former high school Spanish language teachers. They had been great role models as well as major sources of inspiration for Sue. Like her Spanish teachers and her mother have done in the past, Sue would love to inspire others to learn. It was her lifetime dream. To inspire just one person will make teaching worthwhile.

During her high school years, Spanish had represented a window to the world outside the classroom for Sue. It was not only an opportunity to learn about other 
cultures, but also about English, her native language. Most importantly, Spanish had been crucial in overcoming a reading and writing disability. Sue read and wrote things backwards in English. When she began learning Spanish, which according to her has a different word order and is less rigid than English, many thing clicked in her mind. Making comparisons between English and Spanish helped her "sort out" the syntax of both languages, to the point that most of her reading and writing disabilities dissipated.

College provided increasing opportunities to become fluent in Spanish and to learn more about the culture. College had also been instrumental in helping her formulate her own theories and beliefs about language learning and teaching.

Through her language classes, Sue had been exposed to several methodologies that went from total immersion in the target language to Spanish classes entirely taught in English.

When Sue first arrived in Central High School, her assigned student teaching site, she did not feel she was entering an unknown territory. After all, she had spent several years as student in high school. Besides, the previous semester as part of the requirements for her methods course, she had spent a few weeks at a local high school, observing experienced foreign language teachers an learning from their craft. However, soon upon entering the student teacher site, Sue realized that coming in a different role was not easy; in fact Sue described it as "creepy" At the beginning, she felt "old" and "out of place". She found herself identifying better with the students. It was only after a few days that Sue started to feel comfortable in her new role as student teacher. She also felt anxious and nervous the very first times she had to stand in front of the students. The following entries in the daily communication journal kept by Sue and her cooperating teacher, attest to the anxiety that Sue was still experiencing two weeks into her journey.

As the day went on, I felt more confident. I was less flustered in the inside, I hope that the butterflies I feel clear, and my head and will start to function better. My mouth feels like it is tied to lead weights. (Communication Journal, 3/2/98).

Another entry the following day stated: 
When is the brain going to start functioning? I still feel not completely together yet. I feel like a puzzle not quite with all the pieces. Hopefully this will calm down soon.(Communication Journal. 3/2/98).

In spite of her internal turmoil, Sue appeared confident and in control in the outside. Her cooperating teacher reassured her that she was doing fine. Soon enough, Sue's feelings of anxiety gave way to other concerns. Uppermost in her mind after the first few days was her desire to build rapport with students and to establish authority at the same time. Sue was busy learning students' names and trying to create a positive atmosphere in her classroom. She made a point of getting to know her students. She enthusiastically greeted and chatted with them as they came in the classroom, she also attended extracurricular activities so that she was better informed of their lives outside the classroom. However, she soon found out that good intentions and enthusiasm were not enough to build rapport. On March 12, Sue wrote in the Communication Journal:

What is it with $4^{\text {th }}$ hour? I've gotten them to calm down, but now they think I'm out to ruin their lives. Ugh. The other classes are talking to me better. How can I improve my ogre image with these students? (Journal of Communication, 12/2/98).

In response to Sue's preoccupation with the fourth-year students, the cooperating teacher wrote:

This is something some students have complained to me about. I don't think you've done anything differently in that hour to inspire this reaction. It might be just clash of personalities. I do think that if you take your outward confidence down a notch and show more of your "work-in-progress" side that some of the reared heads might lower. (Journal of Communication, 12/2/98).

Establishing a good working relationship with her cooperating teacher was also important for Sue. At first, she thought that Mrs. Smith was quite flexible and laid back. Sue viewed her role as a guide who was there to help her out and make sure that she stayed on the right path. However, as early as February 27, the second week of Sue's student teaching, she became more aware of the role she was expected to play vis-a-vis her cooperating teacher as illustrated in the following entry in the Communication Journal. 
I have really appreciated the comments you have written on the cards. They are truthful and fair. I agree with them $100 \%$ as far as interactions with the class. I first want to say I am here to learn and you to teach me. If there is something you feel should be done differently or something is needing to be said, then by all means, especially if it is MUY IMPORTANTE say it.

Hopefully, I will start thinking of those "cosas importantes" and your comments will start thinning out. But now, they don't bother me at all, in fact they are really training me how to think like a teacher. (Communication Journal, 27/2/98).

Sue's awareness of her position within the cooperating teacher/student teacher dyad was revealed in this entry. She acknowledged that the role of the cooperating teacher was to offer suggestions and criticism, but her apparent willingness to accept Mrs. Smith' suggestions was not devoid of internal tensions and resistance; these conflicting feelings would accompany Sue throughout all her student teaching term. The power relation inherent in such relationship would prove to be the most challenging and difficult aspect of student teaching for Sue. Sarah Smith' mentoring style was controlling and affected Sue's student teaching experience remarkably as will be described below.

As mentioned before, besides Sue's desire to build rapport with her students, was her need to assert her self and to establish authority in the classroom. On February 27, she wrote in the Communication Journal: "I need to establish myself as firm and in a way that will have lasting effect". Her cooperating teacher, on her part, was constantly encouraging her to be firm and maintain the control of the class. Some entries attesting to that are:

Keep a tighter rein on discipline. An informal atmosphere in class is fine as long as it's not too lax. I recommend less slang and more strictness here at the beginning. (Communication Journal,27/2/98).

Crack down on snippy comments and wildness right away. (Communication Journal, 5/3/98).

Get better control. Lots of snippiness and chatter. (Communication Journal, 8/3/98). 


\section{ARTICLES}

For crowd control, firm. To the point. In a statement not a question. "Sit down" Not "Would you please sit down?" (Communication Journal, 15/3/98).

In encouraging Sue to establish authority, Mrs. Smith used the same authoritarian tone she suggested Sue employed with her students as the previous journal entries show. On one hand, Mrs. Smith was asking Sue to assume her teacher role and claim authority, and on the other hand, she was treating her like a student. These conflicting behaviors displayed by Mrs. Smith accentuated the ambiguity of Sue's role.

Another factor complicating Sue's efforts to claim her teacher role was Mrs. Smith's territorial attitude. This was manifested in her constant presence and vigilant stance in the classroom. Sue noted that Mrs. Smith rarely absented herself from her desk. She did not seem to trust Sue enough to leave her in charge, and it was only in the rare occasions when Mrs. Smith left the classroom that Sue was able to relax and feel that she could be her own self. Mrs. Smith also had a practice of correcting Sue in front of the students which made her feel awkward as the following entry illustrates.

There have been occasions in which I have said something wrong. Once I confused este with ese, just because I was so nervous about what the kids were doing. There were two kids talking in the back of the classroom and doing something they shouldn't have been doing; so I was thinking about that in the back of my head and I confused teaching este and ese and she was like, "Oh that's not right" and so she stopped the class and that was so awkward. But it was a good thing that she did it because otherwise they would have learned that incorrectly. (Interview No. 2, 4, 16, 98).

Although Mrs. Smith apologized profusely in the Communication Journal for her interventions and although Sue seemed to understand her intentions, these disruptions undermined Sue's confidence and compromised her credibility in front of students thus complicating her ability to claim authority.

The impact of the conflicting nature of Sue's position was revealed in both interviews. In an intense and somehow cathartic account, Sue talked about the turmoil of this experience. With heartfelt emphasis, she expressed how "hard", how "difficult", how "rough" and how "awkward" the daily power struggles with her cooperating teacher had made student teaching. It was very complicated 
to balance her needs to remain herself while at the same time meeting the expectations of her cooperating teacher. The following excerpt from the data illustrates Sue's feelings.

It's hard because it's not my classroom, and at the same weird time and space, it's not my cooperating teacher's classroom either. So, she's really in charge of what's happening but at the same time, I am the one who is the teacher, that's standing in front of the classroom, grading all the papers, working where they are and stuff. She just has to observe and make sure that things are going on the right track. At the same time, it's hard because we have two different personalities, way too different personalities. And if I do something that is like my personality and she perceives as wrong, as different, where the kids will be confused by that, then she can say "Hey, you did this wrong" . "You have to do it this way". "Make sure you do it this way". This is going to be your classroom for ten weeks, but not really, because there is always gonna be Ms. Sara Smith sitting in the back staring at you, making sure that you do exactly the same thing with her students that she would do. And it's hard. You just feel anxious, you feel nervous. Am I doing the right thing that Ms. Sara Smith wants me to do? (Interview 2, 16/4/98).

As Sue tried to do things the way her cooperating teacher wanted them done, in the back of her mind she painted scenarios of how different things would be when she had her very own classroom. As a coping strategy, Sue also imagined an ideal system where there were no cooperating teachers. An entire year of student teaching with only her supervisor coming once a week for a full day to make sure that things were running smoothly. In Sue's mind, the current system was far from being the ideal way for developing her teaching style. She needed to be able to experiment and do things her way and see if they worked. But in her current situation doing that meant having her cooperating teacher say. 'Oh, that won't work because of this, that won't work because of that. "That was not the way Sue learned. At times, she felt that she was painting too negative a picture of student teaching and of her cooperating teacher. Sue reiterated time and time again that there were many positive aspects to her experience as well. She had learned a lot from her cooperating teacher, "stuff" that she had nor learned in her methodology class. In fact, Mrs. Smith had allowed her to photocopy all her resource files. Besides, she had provided guidance and support. In the second interview, Sue noted 
My cooperating teacher has always been real supportive of me, she really has. She has been great. I don't want any negative to come out. She really has done a great job at supporting me. But still there are those moments when it's just a question mark. Who is in charge of the class? And that's so difficult. It's not my classroom completely so I don't feel complete freedom to go in there and do something. I feel like I'm in a little box. I feel like I have so many things I can't do, or have to do in a certain way, and have to make sure I do it this way, and it's hard. (Interview 2, 16/4/98).

Sue could understand where her cooperating teacher was coming from. She was able to step in her shoes and view the situation from her standpoint. Mrs. Smith was looking out for her kids, making sure that they were learning the right thing and that they would not get too confused by the process of having two teachers. Sue understood that it was not a personal thing; it was the system. All her peers were going through the same rough times. In their conversations, when Sue mentioned the little daily power struggles with her cooperating teacher, they knew exactly what she was talking about. Sue was glad she had her peers as support system; otherwise, she would feel like a "total loser." But frankly, she could not wait for student teaching to be over. During our last interview and with heartfelt emphasis, Sue said

All the people, all the student teachers right now, they all have three more weeks left; all the high school student teachers anyway. And we are all just going there more weeks! Three more weeks! Three more weeks! Ahhhh. So right now our conversation has pretty much died down to three more weeks. It's an anxious time and we will be glad when is over. We are glad it happened. It was a good thing to happen. It is a good thing to have a cooperating teacher to help you out. But all of those little daily power struggles and personality clashes just make it so hard.(Interview 2, 16/4/98).

\section{DISCUSSION AND IMPLICATIONS}

Sue's story uncovers some issues prospective teachers encounter in their quest for professional identity. Sue did not come to student teaching with a blank slate. She brought with herself strong motivation to teach, a deeply ingrained set of beliefs, clear images of the kind of teacher she wanted to become, and 
influential previous language learning experiences. Soon upon entering the field experience, Sue found herself in the ambiguous place in which student teachers are positioned; she was neither a full-fledged teacher nor a student. In trying to negotiate a teaching role for herself, Sue was pulled in different directions, she soon became aware of the powerful position of the cooperating teacher and of her vulnerability within the mentoring relationship. The main tension was manifested in Sue's struggle to develop her own teaching persona on the one hand, and the pressure to conform to her cooperating teachers' expectations on the other hand. Her cooperating teacher's mentoring style exacerbated the power relations inherent in this professional relationship. The mentoring practices exhibited by Mrs. Smith consciously or unconsciously aimed at exerting control and kept Sue in an uncertain territory during all her student teaching. Mrs. Smith seemed unwilling or unable to provide Sue with the space she needed to fully develop her teaching style.

A number of authors have discussed the highly personal and idiosyncratic nature of the cooperating teacher/student teacher relationship (Agee, 1996; Graham 1993; Sudzina, Giebelhaus, E Coolican, 1997). They argue that such relationship (Agee, 1996; Graham 1993; Sudzina, Giebelhaus, \& Coolican, 1997): They argue that such relationship is complicated by the life histories and personalities of the two actors. Although it is true that some cooperating teachers are willing to confer their student teachers with equal power and status in the classroom and provide the space they need to develop their teaching styles; it is also true, that too often this relationship is plagued by tensions and power conflicts as happened in Sue's case.

The findings of this study underscore the importance of uncovering and exposing the dilemmas, tensions, and power conflicts embedded in the student teacher/cooperating teacher relationship. There is a serious need for critical understanding of and reflection on how these relationships are constructed and how they shape student teachers' emerging identity. They also highlight the need for all actors implicated in language teacher preparation to work collaboratively to enhance the student teaching experience so that is lived more as a productive learning process than as an act of endurance (Britzman, 1991).

It is the responsibility of university placement offices in collaboration with teacher educators and university supervisors to identify those cooperating teachers who are better suited for mentoring student teachers. Understandably, 
some cooperating teachers are not willing to work with them and resent the added responsibility and the disruption that student teachers bring into their already crowded work lives.

The university should also provide the support that cooperating teachers need and the recognition that they deserve as crucial actors in the learningto-teach endeavor. The fact that cooperating teachers are experienced practitioners does not make them automatically teacher educators. Koener (1993) suggests the creation of training seminars for cooperating teachers in which they are invited to critically reflect on their roles and on their mentoring styles. Becoming more aware of how their mentoring practices affect the world of the student teacher may influence the way they define their roles as cooperating teachers. Through these seminars, they can also become more knowledgeable about the developmental stages of student teachers and learn effective ways to provide guidance and constructive criticism. However, the responsibility for the development of positive mentoring relationship should not be thrust upon the cooperating teacher only. Zeichner (1983) suggests that student teachers need to be more proactive and take more responsibility in the negotiation of healthy professional relationships with their cooperating teachers. Teacher educators can also contribute to enhancing the student teaching experience by providing student teachers with the tools for critical understanding of their emerging identity as well as a safe environment in which they can openly and honestly reflect upon the tensions, conflicts, dilemmas they encounter during their student teaching term.

Finally, teacher educators and university supervisors should step in whenever difficult situations arise. They can serve as mediators and foster an open, productive and honest dialogue between the cooperating teacher and student teacher.

Student teaching is a crucial stage in the socialization of prospective teachers into the culture of teaching, one often characterized by crisis and contradictions. The transition from student to teacher is often problematic and plagued by conflicting expectations, which can make this experience increasingly difficult as Sue's case revealed. In order to assist effectively student teachers that find themselves in similar situations we need to have a more clear understanding of the complexity and demands of their dual role as students and teachers. Sue's case study has shed some light into issues of power 
embedded in the student teacher/cooperating teacher relationship. Given the design of this study, only Sue's perspective was examined. More studies need to be conducted that uncover the perspectives of the other actors implicated in the socialization process of student teachers, namely cooperating teachers, teacher educators and university supervisors.

Although this study was conducted in the United States, its findings are relevant for language teacher education programs that are structured in a similar way, such as those of Colombia. Since Colombian prospective teachers have to work closely with cooperating teachers during their student teaching, they might have to confront realities similar to the ones faced by participants of this study; therefore, language teacher educators in Colombia may find the implications drawn in this study useful for their practice.

\section{REFERENCES}

Agee, J. M. (1996) "I was kind of hoping for a woman" Issues of lived experience in the preservice-cooperating teacher relationship. English Education, 28,280-302.

Britzman, D. P. (1991). Practice Makes Practice: A critical Study of Learning to Teach. Albany, New York: State University of New York Press.

Carel, S., Stuckey, A., Spalding, A., Parish, D., Vidaurri, L., Dahlstrom, K., \& Rand, C. (1996). Voices from the trenches. In Z. Moore. (Ed.) Foreign Language Teacher Education (pp. 317- 332). New York: University Press of America.

Graham, M. (1993), Curious positions: Reciprocity and tensions in the student teacher/cooperating teacher relationship. English Education, 25, 213-230.

Knowles, J.G. \& Cole, A.L. (1994). Through Preservice Teachers`Eyes: Exploring Field Experiences through Narrative Inquiry. New York: Macmillan.

Kvale, S. (1996). InterViews. California: SAGE Publications.

Koener, M.E. (1992). The cooperating teacher: An ambivalent participant in student teaching. Journal of Teacher Education, 46 - 56.

Moustakas, C. (1994). Phenomenological Research Methods. California: SAGE Publications.

Strauss, A., E Corbin, J. (1990). Basics of qualitative research. Newbury Park: 
SAGE Publications.

Sudzina, M., Giebelhaus, C. \& Coolican, M. (1997). Mentor or tormentor: The role of the cooperating teacher in student teacher success or failure.

Action in Teacher Education, 3, 23, 35.

Weber, S. E Mitchell, C. (1996). Betwixt and between: The culture of student teaching. In Z. Moore. (Ed.) Foreign Language Teacher Education (pp. 300316). New York: University Press of America.

Yin, R.K. (1984). Case study research. Beverly Hills, CA: Sage Publications.

Zeichner, K. M. (1983). Alternative paradigms of teacher education. Journal of Teacher Education, 34, 3-9. 